Prof. H. W. Melville, F.R.S.

Prof. IH. W. Melville, who will succeed Sir Norman Haworth at Birmingham, has made many valuable contributions to our knowledge in the field of reaction kinetics. His early work consisted in the examination of the various explosion limits in such mixtures as phosphine and oxygen. The implications of the free radical in such reactions led him to explore the mechanism of a number of photochemical reactions in which radicals are found, and here he first introduced the device of the rotating sector which has permitted us to obtain life-times of transient species with remarkable accuracy.

Some fifteen years ago when deuterium and its compounds became readily available, Melville examined a number of gas reactions in which hydrogen could be replaced by deuterium in order that the relative importance of mass and zero-point energy could be evaluated, thus throwing light on the detailed mechanism. With this background Melville felt that he was in a position to take up the suggestion that the study of the more complex processes of polymerization and macromolecular condensation might, if carried out in the gaseous phase, yield valuable information on the nature of the chain reactions involved. He threw himself into this work, both in the Department of Colloid Science at Cambridge and later at the University of Aberdeen, with his characteristic energy, and the continuous stream of papers in this field coming from these laboratories bears witness to his versatility and ingenuity in unravelling the complexities of these reactions. The School of Physical Chemistry which he created at Aberdeen combined in a characteristic manner the experimental with the theoretical. Birmingham is to be congratulated in its choice.

\section{Genetics at Birmingham : Dr. K. Mather}

DR. KENNETH MATHER, who has been appointed to the chair of genetics now established in the University of Birmingham, is known for his, in some respects, revolutionary outlook on this subject. Dr. Mather derives this outlook from a fusion of several of the main streams of thought in biology. He went from Manchester in 1931 to work at the John Innes Horticultural Institution, where he obtained a thorough grasp of the chromosome theory of heredity as it was being developed there at the time. In 1933 he went for a year to Sweden, where he gained a great deal from studying the methods of plant breeding used at Svalöv and by that notable sugar beet breeder, Dr. J. M. Rasmusson. In 1934 he took a post with Prof. R. A. Fisher, under whom he became familiar both with the breeding of mice and the still rapidly developing technique of statistical genetics, to which he began to make serious contributions. In 1937 he spent a year with Morgan and East in the United States. Finally, in 1938 he returned to take up the post of head of the Genetics Department at the John Innes Institution. There he has remained for ten years carrying out (with a success that has now been recognized) the very definite purpose and programme that he had in mind when he went there-that of combining biometry and genetics into a single efficient tool for the study of evolution, the practice of plant and animal improvement and the understanding of biology as a whole. During these years, however, Dr. Mather, like other workers in this field, has been painfully conscious of the widening gap between the advances of genetic research and the status of genetic teaching in the universities. In his new post he will have an opportunity of narrowing this gap and of rendering a great service to the University of Bir. mingham.

\section{British Jute Trade Research Association}

The British Jute Trade Research Association has acquired premises on the Dundee Industrial Estate to replace the temporary accommodation at present occupied in Bellfield Street, Dundee, following negotiations with the Scottish Industrial Estates, Ltd., and various Government committees. The new buildings will be utilized for future research and development in connexion with the activities of the Association, and it is hoped to be in occupation early in 1949. When completed, the Laboratory Section will cover an area of approximately 6,500 sq. ft., and will contain physical and chemical laboratories, photographic and physical dark rooms, a room where constant temperature and humidity can be maintained, machine rooms, library and administration. A separate Engineering Development Section will in the first instance cover an area of some 2,000 sq. ft., and the personnel in this Section will work in very close collaboration with the Laboratory scientific staff. The remaining space of 14,000 sq. $\mathrm{ft}$. will be devoted to the Processing Section, in which will be installed a complete range of all jute processing, weaving and finishing machinery. The building will be the first industrial research laboratory of its kind to be set up in Scotland for co-operative research, and is supported by practically the whole of the jute interests. The importance of scientific research to the industry is being realized more and more, and the support for the project illustrates the desire of the industrialist to utilize every possible means to increase efficiency and quality of product.

\section{Science and Technology in China}

THE Natural Science Society of China has recently inaugurated a new bulletin, Science and Technology in China, of which two numbers of the first volume have already appeared. It is very well printed and produced and contains many interesting articles. In the April issue, Dr. Mao I-Sheng writes on the present position and outlook of research in the engineering sciences in China; Dr. Li Ching-Yuan on current mineral exploration in China; and Dr. Jen Mei-O on the progress of land utilization surveys in the southwest part of the country. The work of the Scientific Office of the British Council in China is reviewed at some length, and the rest of the bulletin consists of research reports similar to the correspondence columns of Nature, together with abstracts of papers read at the February 1948 meeting of the Chinese Chemical Society at Nanking. While China has had for many years its chief scientific journal analogous to Nature, namely, Ko-Hsueh, this has always been and will continue to be published in the Chinese language. There has therefore been room for a periodical, perhaps of a smaller character but in the English language, and the new venture deserves every success. The chief editor is Dr. Wu HsuehChou (director of the Chemical Institute of Academia Sinica), and inquiries and subscriptions should be addressed to him at that Institute, 320 Yoyang Road, Shanghai. Foreign subscribers may also communicate with Mr. S. H. Doo, 7137 Pennsylvania Avenue, Pittsburgh 8, Pa., U.S.A. The annual subscription is 2.00 American dollars per annum, or its equivalent. 